\title{
Tindak Pidana Agama Menurut Perspektif Hukum Islam, Hukum Positif dan Hak Asasi Manusia
}

\author{
Didi Hilman ${ }^{1}$ \\ Universitas Ibn Khaldun Bogor, Jawa Barat \\ doi https://doi.org/10.32507/mizan.v3i2.491
}

\begin{abstract}
Religious crime has been known since the days of Ancient Greece. All religions in the world prohibit criminal acts against religion. Al-Qur'an as the first source in Islamic law prohibits religious crime, but does not specifically regulate the type and form of punishment. Indonesia's positive law prohibits religious criminal offenses in various laws, such as Law Number 1/PNPS/1965 concerning Prevention of Abuse and/or Blasphemy in Religion, Book of Criminal Law Article 156 a, and Law Number 11 Year 2008 about Information and Electronic Transactions. Today, the existence of religious offenses is at issue because it is considered to be contrary to the principles of human rights. This study aims to explore religious crime from the perspective of Islamic law and positive law related to human rights. This research is a normative law research (Legal Research) with a normative juridical approach. This research is analytical descriptive, that is, research that reveals laws and regulations relating to legal theories which are the object of research. Data obtained through library research are then analyzed using the theory of maqosid al-shariah, the theory of religious crime (blasphemy), the theory of human rights, the theory of religious and state relations, and the theory of loss (harm principle). Based on this research, it can be concluded that according to Islamic law, religious crimes are acts that defile (tadnis), insult (istihza), make fun of (syatama), revile (saba) and curse (taq) Allah and His Messenger, the Book Holy Al-Qur'an, attacking the Islamic creed, and doing actions that deviate from the demands of Islamic teachings (bid'ah). Whereas according to positive law, religious crime is divided into heresy, blasphemy, defamation of religion, and invites others not to have a religion (Article 156a of the Criminal Code), expressions of hatred towards groups on the basis of religion (Article article) 156 of the Criminal Code), criminal offenses related to religion such as disrupting religious activities and worship (Articles 175, 176, 177 1st and 2nd, 178, 179, 180, 181, 503 2nd Penal Code).
\end{abstract}

Keywords: Religious Crime, Islamic Maqosid, Human Rights, Islamic Human Rights, Harm Theory

\footnotetext{
* Naskah diterima tanggal: 12 Januari 2020, direvisi: 15 Februari 2020, disetujui untuk terbit: 2 Maret
} 2020.

${ }^{1}$ Didi Hilman adalah dosen tetap Fakultas Agama Islam Universitas Ibn Khaldun Bogor, Jawa Barat Indonesia. E-mail: didi.hilman@fai.uika-bogor.ac.id 


\begin{abstract}
Abstrak
Kejahatan agama sudah dikenal sejak zaman Yunani Kuno. Semua agama di dunia melarang tindakan kriminal terhadap agama. Al-Qur'an sebagai sumber pertama dalam hukum Islam melarang kejahatan agama, tetapi tidak secara spesifik mengatur jenis dan bentuk hukuman. Hukum positif Indonesia melarang tindak pidana agama dalam berbagai undang-undang, seperti Undang-Undang Nomor 1 / PNPS / 1965 tentang Pencegahan Penyalahgunaan dan / atau Penistaan Agama, Kitab Undang-Undang Hukum Pidana Pasal 156 a, dan UndangUndang Nomor 11 Tahun 2008 tentang Informasi dan Transaksi Elektronik. Saat ini, keberadaan pelanggaran agama menjadi masalah karena dianggap bertentangan dengan prinsip-prinsip hak asasi manusia. Penelitian ini bertujuan untuk mengeksplorasi kejahatan agama dari perspektif hukum Islam dan hukum positif yang terkait dengan hak asasi manusia. Penelitian ini merupakan penelitian hukum normatif (Penelitian Hukum) dengan pendekatan yuridis normatif. Penelitian ini bersifat deskriptif analitik, yaitu penelitian yang mengungkap hukum dan peraturan yang berkaitan dengan teori hukum yang menjadi objek penelitian. Data yang diperoleh melalui penelitian kepustakaan kemudian dianalisis menggunakan teori maqosid al-syariah, teori kejahatan agama (penistaan), teori hak asasi manusia, teori agama dan hubungan negara, dan teori kerugian (prinsip kerugian). Berdasarkan penelitian ini, dapat disimpulkan bahwa menurut hukum Islam, kejahatan agama adalah tindakan yang menajiskan (tadnis), menghina (istihza), mengolok-olok (syatama), mencaci maki (saba) dan mengutuk (taq) Allah dan Rasul-Nya, Kitab Suci AlQur'an, menyerang akidah Islam, dan melakukan tindakan yang menyimpang dari tuntutan ajaran Islam (bid'ah). Sedangkan menurut hukum positif, kejahatan agama dibagi menjadi bidat, penistaan agama, pencemaran nama baik agama, dan mengundang orang lain untuk tidak beragama (Pasal 156a KUHP), ekspresi kebencian terhadap kelompok berdasarkan agama (Artikel artikel) $156 \mathrm{KUHP}$ ), pelanggaran pidana yang berkaitan dengan agama seperti mengganggu kegiatan keagamaan dan ibadah (Pasal 175, 176, 1771 dan 2, 178, 179, 180, 181, 503 2nd KUHP).
\end{abstract}

Kata Kunci: Kejahatan Agama, Maqosid Islam, Hak Asasi Manusia, Hak Asasi Manusia Islam, Teori Bahaya

\title{
A. PENDAHULUAN
}

Dilihat dari persepektif sosiologis-antropologis, agama adalah suatu sistem keyakinan yang dianut dan tindakan-tindakan yang diwujudkan oleh suatu kelompok atau masyarakat dalam menginterpretasi dan memberi respon terhadap segala sesuatu yang dirasakan dan diyakini, sebagai yang ghaib dan suci. ${ }^{2}$ Bagi para penganutnya, agama berisikan ajaran-ajaran mengenai kebenaran tertinggi dan mutlak tentang eksistensi manusia dan petunjuk-petunjuk untuk hidup selamat di dunia dan akhirat, yaitu sebagai manusia yang takwa kapada Tuhannya.

Bangsa Indonesia merupakan bangsa yang religius, memiliki kepercayaan dan hubungan dengan Tuhan, dinyatakan dalam sikap hidup yang didasarkan kepada ajaran agamanya. Bagi bangsa Indonesia, agama mempunyai peranan yang sangat penting. ${ }^{3}$ Oleh karena itu dalam kehidupan bernegara, agama tidak dapat dipisahkan. Agama dan syariat agama dihormati dan ditempatkan dalam nilai asasi kehidupan

${ }_{1}$ Parsudi Suparlan, Pengantar buku Sociology of Religion, editor Roland Robertson, terjemahan Indonesia: Agama Dalam Analisa dan Interpretasi Sosiologis, pent. Achmad Fedyani Saiduddin, Jakarta: Radjawali, 1988, hlm. V.

3 Sekretariat Jenderal Departemen Agama Republik Indonesia, Buku Pedoman Dasar Kerukunan Hidup Beragama 1985 - 1986, Proyek Pembinaan Kerukunan HidupBeragama, Jakarta, 1986, hlm. 2.. 
bangsa dan negara. Agama dilindungi dari penghinaan, penyalahgunaan, penodaan dan pemahaman yang dianggap keliru. Negara mendukung pengamalan dan pemahaman agama yang original dan rasional dalam rangka kenikmatan hidup dunia dan akhirat.

Meskipun bangsa Indonesia memposisikan agama sebagai nilai-nilai yang asasi dalam kehidupan berbangsa dan bernegara, namun tindak pidana agama kerap kali terjadi. Kasus-kasus tindak pidana agama dapat diurut hingga masa sebelum penjajahan. Di zaman kolonial, penghinaan terhadap Nabi Muhammad SAW yang dilakukan oleh Martodharsono dan Djojodikoro dalam majalah Djawi Hisworo edisi 9 dan 11 Januari 1918, telah menimbulkan protes dan kemarahan umat Islam. Kedua penulis tersebut mengatakan bahwa Nabi Muhammad SAW adalah 'seorang pemabuk' dan 'penghisap candu'. Penghinaan terhadap Nabi Muhammad SAW ini tidak diproses ke pengadilan. ${ }^{4}$

Pada masa Orde Lama, penghinaan dan penodaan terhadap agama kerap dilakukan oleh Partai Komunis Indonesia (PKI) melalui organisasi mantel di bawahnya seperti Pemuda Rakyat dan Lembaga Kesenian Rakyat (Lekra). Penghinaan dan penodaan terhadap agama dilakukan melalui berbagai pementasan kesenian rakyat yang dikoordinir oleh Lekra, seperti reog, ludruk, ketoprak dan wayang kulit, terutama di Jawa Timur dan Jawa Tengah. ${ }^{5}$

Di zaman Orde Baru, kasus tindak pidana agama (blasphemy) diawali dengan cerita pendek 'Langit Makin Mendung' dalam majalah 'Sastra' pada tahun 1968. Kemudian berturut-turut terjadi dalam kasus Arswendo Atmowiloto pada tahun 1990, serta kasus Permadi pada tahun 1993. Di era reformasi, tindak pidana agama terjadi dalam beberapa kasus, antara lain kasus Lia Aminudin atau Lia Eden pada tahun 2006, kasus Tajul Muluk pada tahun 2012, kasus Gerakan Fajar Nusantara (Gafatar), dan kasus Basuki Tjahaja Purnama alias Ahok. Di samping maraknya kasus-kasus tindak pidana agama di tanah air, terjadi juga pro dan kontra terhadap keberadaan Undang-Undang Nomor 1 PNPS Tahun 1965 Tentang Pencegahan Penyalahgunaan dan/atau Penodaan Agama. Mereka yang kontra, beralasan bahwa undang-undang tersebut berpotensi melanggar hak-hak asasi manusia.

Tulisan ini ingin meneliti tentang perbuatan-perbuatan yang dikualifikasi sebagai tindak pidana agama jika dilihat dari perspektif hukum Islam, hukum positif, dan hak-hak asasi manusia. Metode yang digunakan dalam penelitian ini adalah adalah metode perbandingan, yaitu membandingkan tindak pidana agama dalam hukum Islam serta hukum pidana positif beberapa negara yang relevan. Selain metode perbandingan, penelitian ini juga menggunakan metode sejarah dan metode sosiologis. Dengan metode sejarah, diteliti perkembangan tindak pidana agama sejak zaman kolonial hingga sekarang, sedangkan dalam metode sosiologis diteliti faktor-faktor sosial yang mempengaruhi perkembangan tindak pidana agama.

\footnotetext{
${ }^{4}$ Deliar Noer, Gerakan Modern Islam di Indonesia 1900-1942, LP3ES, Jakarta, 1980, hlm 143.

${ }^{5}$ Abdul Muin D.Z. Benturan NU-PKI 1948-1965, PB.NU. Jakarta, 2014, hlm 96-104.
} 


\section{B. METODE PENELITIAN}

Penelitian ini juga menelusuri keberadaan undang-undang tindak pidana agama dilihat dari perspektif hak asasi manusia. Penelitian ini merupakan penelitian hukum normatif atau legal research, oleh karena itu metode pendekatan yang digunakan dalam penelitian ini adalah pendekatan yuridis normatif. Pendekatan yuridis normatif tersebut, mengacu kepada norma-norma hukum yang terdapat dalam peraturan perundang-undangan dan putusan-putusan pengadilan serta norma-norma hukum yang ada dalam masyarakat. Selain itu, dengan melihat sinkronisasi dan harmonisasi suatu aturan dengan aturan lainnya secara hierarki. ${ }^{6}$

\section{ANALISIS DAN PEMBAHASAN}

\section{Pengertian Tindak Pidana Agama}

Tindak pidana agama dapat dibedakan menjadi tindak pidana penyimpangan terhadap agama (heresy), tindak pidana penodaan (blasphemy), penistaan (defamation) dan propaganda atheism, serta tindak pidana yang berkaitan dengan agama. Dalam Islam, tindak pidana agama adalah perbuatan menghina Tuhan, Nabi Muhammad SAW dan nabi-nabi yang diakui dalam Al-Qur'an serta menghina Al-Qur'an itu sendiri. Tindak pidana agama dalam istilah Bahasa Arab dinamakan jinayah atau jarimah. Tindak pidana agama identik dengan penghinaan, pelecehan, pencemaran, merusak, atau mengolok-olok terhadap suatu agama. ${ }^{7}$

Al-Qur'an mengatur tentang tindak pidana agama. Sebaliknya, pandangan bahwa Al-Qur'an tidak mengatur hal tersebut adalah kesalah-pahaman (misconceptions). Dalam beberapa kasus, Al-Qur'an hanya memberikan pedoman dan perintah dasar, sedangkan hal-hal yang lebih rinci dijelaskan oleh Rasulullah SAW. Al-Qur'an mengatur tentang tindak pidana agama bagi penghina agama, seperti dalam terjemah dari ayat berikut:

"Hukuman bagi orang-orang yang memerangi Allah dan Rasul-Nya dan membuat kerusakan di muka bumi, hanyalah dibunuh atau disalib, atau dipotong kaki dan tangan mereka secara silang, atau diasingkan dari tempat kediamannya. Yang demikian itu kehinaan bagi mereka di dunia, dan diakhirat mereka mendapat azab yang besar. Kecuali orang-orang yang bertobat sebelum kamu dapat menguasai mereka; maka ketahuilah, bahwa Allah Maha Pengampun, Maha Penyayang". ${ }^{8}$

Sanksi pidana bagi pelaku penghina atau penista agama (blasphemers) berlaku baik bagi Muslim maupun Non-Muslim. Beberapa kasus tindak pidana agama yang telah dipidana sewaktu Rasulullah SAW masih hidup yaitu ketika beliau memerintahkan sahabatnya untuk membunuh seorang Yahudi yang bernama Kab bin

${ }^{6}$ Zainuddin, Metode Penelitian Hukum, Sinar Grafika, Jakarta, 2009, hlm. 105.

${ }^{7}$ Muhammad Dahri, Tindak Pidana Penodaan Agama di Indonesia: Tinjauan Pengaturan Perundangundangan dan Konsep Hukum Islam, dalam at-Tafahum: Journal of Islamic Law, Vol. 1 N 2 Juli- Desember 2017, hlm. 62

${ }^{8}$ Al-Qur'an Surat Alma'idah (V) ayat 33-34. 
Al-Ashruf. ${ }^{9}$ Nabi S.A.W mengirim Abdullah bin Ateeq RA untuk membunuh seorang Yahudi yang bernama Abu Rafayation alias Abu Rafay..$^{10}$ Tindak pidana agama berbeda dengan tindak pidana murtad (riddah), pemberontakan (baghyu) dan perampokan (hirabah).

Semasa Rasulullah SAW, tidak ada orang yang dihukum karena melakukan murtad. ${ }^{11}$ Mereka yang dieksekusi pada masa itu karena mereka melakukan tindak pidana yang lain. Eksekusi pidana terhadap mereka yang tidak mau membayar zakat di masa khalifah pertama, lebih merupakan pembangkangan kepada pemerintah pusat ketimbang karena murtad. ${ }^{12}$ Hanya pada masa daulah Umayyah dan Abbasiyah terjadi eksekusi pidana terhadap mereka yang dipandang murtad. Islam memberikan kebebasan kepada masyarakat untuk menganut suatu agama atau satu sistem keyakinan sesuai dengan pilihan mereka, dan tidak seorangpun dibenarkan untuk memaksakan agama Islam dengan kekuatan dan kekerasan. ${ }^{13}$

Pemahaman murtad di masa lalu berbeda konteksnya dengan sekarang. Murtad dimasa lalu bukan sekedar berganti agama, atau keluar dari Islam, tetapi berhubungan erat dengan permusuhan terhadap Islam. Orang yang murtad di masa itu terlibat dalam propaganda melawan Islam dan menyatu dengan tentara lawan. Jadi memiliki bentuk politik, kultural dan militer melawan umat Islam.

\section{Tindak Pidana Agama dalam Hukum Positif Indonesia}

Tindak pidana agama dalam hukum pidana Indonesia diatur dalam Pasal 156 dan 156-a Kitab Undang-Undang Hukum Pidana (KUHP); Undang-Undang Nomor 1/PNPS/1965 tentang Pencegahan Penyalahgunaan dan/atau Penodaan Agama; serta Undang-Undang Nomor 11 Tahun 2008 tentang Informasi dan Transaksi Elektronik yang diperbaharui oleh Undang-Undang Nomor 19 Tahun 2016 tentang Perubahan Atas Undang-Undang Nomor 11 Tahun 2008 Tentang Informasi dan Transaksi Elektronik.

Tindak pidana agama baru masuk ke dalam KUHP Indonesia setelah keluarnya Penetapan Presiden Nomor 1 Tahun 1965 Tentang Pencegahan Penyalahgunaan dan/atau Penodaan Agama. Pasal 4 Penetapan Presiden tersebut menegaskan bahwa pada Kitab Undang-Undang Hukum Pidana diadakan pasal baru, yaitu Pasal 156a yang berbunyi sebagai berikut;

“Dipidana dengan pidana penjara selama-lamanya lima tahun barangsiapa dengan sengaja di muka umum mengeluarkan perasaan atau melakukan perbuatan yang pada pokoknya bersifat permusuhan, penyalahgunaan atau penodaan terhadap suatu agama

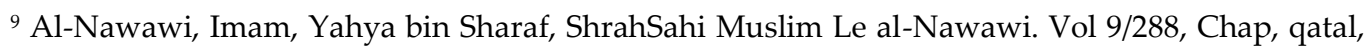
Kab'bin Al Ashraf, Dar al-Kutub al-Ilmiyyah Beirut.

10 Al-Bukhari, Imam, Abu Abdullah Muhammad 'ibn 'Ismail, al-Jami al-Musnad al-Sahih alMukhtasar min umur RasulAllahwasynanihiwaayyamini. Bab, "Katl-e- 'AbiRafy", Vol. 12/432s, DarTawq al-Najah.

\footnotetext{
${ }^{11} \mathrm{Ibid}$ hlm 8

12 ibid

13 ibid hlm 10
} 
yang dianut di Indonesia, dengan maksud agar supaya orang tidak menganut agama apa pun juga, yang bersendikan Ketuhanan Yang Maha Esa."

Tindak pidana agama dalam hukum positif Indonesia dapat dibedakan menjadi:

a. Tindak pidana agama, yaitu perbuatan-perbuatan yang menyimpang dari ajaran agama (heresy), perbuatan-perbuatan yang menodai agama (blasphemy), menista agama (defamation of religion), dan mengajak orang tidak beragama (atheism) yang diatur dalam Pasal 156a KUHP, serta perbuatan atau ekspresi kebencian terhadap golongan agama (hate speech), seperti yang diatur dalam Pasal 156 KUHP; dan

b. Tindak pidana yang berhubungan dengan agama, yaitu; a) Perbuatan-perbuatan yang dilarang dalam Pasal $175 \mathrm{KUHP}$, yaitu merintangi pertemuan/upacara agama dan upacara penguburan jenazah; b) Perbuatan-perbuatan yang dilarang dalam Pasal 176 KUHP, yaitu mengganggu pertemuan/upacara keagamaan dan upacara penguburan jenazah; c) Perbuatan-perbuatan yang dilarang dalam Pasal 177 ke-1 yaitu mentertawakan petugas agama dalam menjalankan tugasnya yang diizinkan; d) Perbuatan-perbuatan yang dilarang dalam Pasal 177 ke-2 KUHP, yaitu menghina benda-benda keperluan ibadah; e) Perbuatan-perbuatan yang dilarang dalam Pasal $178 \mathrm{KUHP}$, yaitu merintangi pengangkutan mayat ke kuburan (Pasal 178 KUHP); f) Perbuatan-perbuatan yang dilarang dalam Pasal 179 KUHP, yaitu menodai/merusak kuburan; g) Perbuatan-perbuatan yang dilarang dalam Pasal 180 KUHP, yaitu menggali, mengambil, memindahkan jenazah; h) Perbuatan-perbuatan yang dilarang dalam Pasal 181 KUHP, yaitu menyembunyikan/menghilangkan jenazah untuk menyembunyikan kematian/kelahiran; dan i) Perbuatan-perbuatan yang dilarang dalam Pasal 503 ke-2 KUHP yaitu membuat gaduh dekat bangunan untuk ibadah atau pada waktu ibadah dilakukan (Pasal 503 ke-2 KUHP).

\section{Delik Agama dan Konstitusi}

Keberadaan tindak pidana agama dalam sistem hukum suatu negara, bergantung pada kaitan antara relasi agama dan negara diatur di dalam konstitusinya. Dalam literatur hukum internasional dapat ditemukan beberapa model atau tipologi relasi agama dan negara, antara lain dikemukan oleh Winfried Brugger, Durham \& Scharffs, Hirschl, dan The International Institute for Democracy and Electoral Assistance (IDEA). Tipologi tersebut dapat disederhanakan menjadi 4 (empat) kategori yaitu;

\section{a. Negara yang Anti Agama (Animosity State Toward Religion)}

Dalam negara yang anti agama, tidak dikenal tindak pidana agama. Negara memusuhi agama, sebagaimana tercermin dalam konstitusi dan kebijakan pemerintahannya. Model seperti ini dipraktikkan oleh negara-negara komunis di masa lalu, seperti Albania, Uni Soviet (USSR), China dan negara komunis lainnya. Mereka tidak mengakui keberadaan agama apapun dan menanamkan cara pandang (world view) yang materialistik dan saintifik pada rakyatnya, serta mendorong propaganda anti 
agama. Sikap permusuhan negara-negara komunis terhadap agama di masa lalu (sebelum runtuhnya Uni Soviet), merupakan konsekuensi logis dari filsafat Karl Marx, pikiran-pikiran Vladimir IIiyich Lenin dan Joseph Stalin, yang melandasi pandangan hidup negara-negara komunis. Karl Marx memandang agama sebagai candu masyarakat. Agama dianggap sebagai kesadaran palsu yang mencerminkan dan mendukung ketidakadilan tatanan sosial.

\section{b. Negara Sekuler (Secular State)}

Dalam negara sekuler, agama tidak dibenarkan berada di wilayah publik. Konstitusi negara menganut prinsip pemisahan antara negara dan agama. Agama merupakan urusan pribadi (private affair), sedangkan negara berada pada ranah publik (public affair), sehingga ada tembok yang memisahkan agama dari negara.

Negara sekuler dapat dibedakan menjadi negara sekuler yang ekstrim, dan negara sekuler yang moderat. Negara sekuler yang ekstrim, sama sekali tidak mentolerir adanya campur tangan negara terhadap masalah agama. Sikap seperti ini merupakan warisan dari konflik gereja dan negara dalam sejarah Eropa di masa lalu. Konflik ini misalnya terjadi di Prancis, Italy dan Spanyol. Meski bentuk konflik dan periode terjadinya berbeda-beda, namun akar pertentangannya tetap sama yaitu perebutan kekuasaan.

\section{c. Negara yang Positif Terhadap Agama (Positive State Toward Religion)}

Dalam negara yang positif terhadap agama, negara tidak mengusir agama dari wilayah publik. Negara mengakui keberadaan agama dalam kehidupannya. Republik Irlandia, Republik Indonesia dan Republik Jerman merupakan contoh dari kategori ini.

\section{d. Negara Agama (Theocracy)}

Dalam negara agama, terjadi penyatuan yang formal agama dan negara. Kewajiban hukum adalah bagian dari kewajiban agama. Pelanggaran terhadap hukum adalah dosa besar. Menurut Winfried Brugger tipe ini dipraktikkan di Iran, dan Arab Saudi.

Pertama, dalam pasal 513 Kitab Undang-undang Hukum Pidana Iran diatur sebagai berikut: ${ }^{14}$

"Setiap orang yang menghina nilai-nilai kesucian Islam atau kesucian para Nabi Besar atau kesucian dua belas imam Syiah, atau kesucian Fatimah putri Nabi Muhammad SAW, apabila perbuatan itu dianggap sebagai sab-al-nabi akan dipidana mati; jika tidak, akan dipidana penjara satu hingga lima tahun."

Kedua, Arab Saudi menyatakan dirinya sebagai negara Islam (Theocratic State). Menurut Pasal 1 Hukum Dasarnya (Basical Law of Saudi Arabia), Kerajaan Saudi Arabia

${ }^{14}$ Article 513 of the old Penal Code which remains in force, states (in translation by Iran Human Rights Documentation Center): "Any person insults the sacred values of Islam or any of Great Prophets or the [twelve Shi'ite] imams or the Holy Fatemeh [daughter of Prophet Mohammad], if considered as sāb-al-nabi shall be punishable by the death penalty; otherwise shall be sentenced to one to five years' imprisonment." 
merupakan Negara Islam yang berdaulat, dengan al-Qur'an dan Sunnah Nabi Muhammad SAW sebagai konstitusinya. Hukum Pidana Arab Saudi berdasarkan pada hukum syari'ah (Sharia Law). Tindak pidana penodaan agama dipandang sebagai penyimpangan dari ajaran Islam Sunni dan menyamakannya dengan murtad. Dalam hukum Saudi Arabia, murtad merupakan kejahatan dan dapat dipidana mati. Hukuman mati (biasanya dilakukan dengan pemenggalan kepala dan penyaliban) juga ditujukan kepada kejahatan sihir dan tenung.

\section{Delik Agama dan Hak Asasi Manusia}

Dalam perspektif Hak-hak Asasi Manusia Barat, keberadaan Undang-Undang tindak pidana agama dipandang sebagai ancaman terhadap hak-hak asasi manusia, yaitu hak atas kebebasan beragama, berekspresi, berpendapat, berpikir, berkeyakinan, dan berhati nurani, serta kebebasan berserikat dan berkumpul. 'Freedom House' suatu lembaga internasional yang bekerja mendukung dan mengadvokasi kebebasan, demokrasi dan hak asasi manusia, dalam laporannya yang berjudul: "Policing Belief: The Impact of Blasphemy Laws On Human Rights" edisi Oktober 2010 mengemukakan sebagaiberikut: ${ }^{15}$

"Di berbagai negara, hukum yang mengkriminalisasi tindak pidana agama (blasphemy) telah termaktub dalam kitab undang-undangnya sejak puluhan tahun yang lalu. Akhirakhir ini kritik terhadap hukum penistaan agama (blasphemy law) semakin menyeruak. Mereka mempertanyakan kebutuhan dan efektifitas hukum tersebut. Namun hukum tersebut masih dipertahankan oleh pemerintah dengan alasan masih diperlukan untuk memelihara kerukunan diantara berbagai kelompok agama. Argumen ini juga telah diupayakan di PBB sebagai bagian dari upaya untuk melarang penistaan terhadap agama pada tataran internasional. Para pendukung proyek ini melihatnya sebagai perluasan kerangka kerja hak asasi manusia yang telah ada. Penghinaan terhadap agama merupakan diskriminasi dan menyebabkan dampak negatif terhadap kebebasan beragama kelompok agama yang dinista. Namun, suatu eksaminasi terhadap pelaksanaan hukum penistaan agama mengindikasikan terjadinya pelanggaran, bukannya perlindungan terhadap hak-hak asasi manusia."

Di tanah air, penolakan terhadap blasphemy law datang dari kalangan inteletual, aktifis hak-hak asasi manusia dan tokoh masyarakat. Mereka beramai-ramai mengajukan ujian materil (judicial review), agar MK (Mahkamah Konstitusi) membatalkan Undang-Undang Nomor 1/PNPS/1965 tentang Pencegahan Penyalahgunaan dan/atau Penodaan Agama. Namun, Mahkamah Konstitusi Republik Indonesia dalam Putusannya Nomor 140/PUU-VII/2009 tanggal 19 April 2010, menolak uji materil tersebut dan tetap mempertahankan keberadaan undang-undang tersebut. Tidak puas dengan putusan MK tersebut, beberapa aktifis dan peneliti hukum yang

${ }^{15}$ A. Freedom House Special Report. Policing Belief: The Impact of Blasphemy Laws on Human Rights, October, 2010, hlm. 1. 
tergabung dalam The Indonesian Legal Resources Center (ILRC) juga melakukan eksaminasi publik. ${ }^{16}$

Menurut The Indonesian Legal Resources Center (ILRC) tujuan Eksaminasi Publik ini adalah untuk mendorong partisipasi publik melakukan pengkajian, pengkritisan, dan penilaian secara objektif atas putusan Mahkamah Konstitusi. ${ }^{17}$ Secara khusus, eksaminasi publik ini juga bertujuan sebagai-berikut: ${ }^{18}$

Pertama, Ketepatan dan konsistensi MK dalam menerapkan asas-asas dan prinsip-prinsip hukum baik hukum materiil maupun formil dalam pengujian permohonan tersebut.

Kedua, Persepektif MK dalam memahami konsep hak atas kebebasan beragama dan berkeyakinan, dengan mendasarkan pada jaminan konstitusi dan kesesuaian dengan standar norma-norma hak asasi manusia internasional.

Ketiga, Kualitas putusan MK, khususnya penerapan asas dan prinsip prinsip hak asasi manusia. Majelis eksaminasi publik menguji kembali norma-norma dalam UU Pencegahan Penodaan Agama yang diajukan Pemohon kepada MK, yaitu lima norma dalam pasal 1 hingga 4 Undang-Undang Pencegahan Penodaan Agama terhadap sembilan norma dalam UUD 1945 yaitu Pasal 1 ayat (3), Pasal 27 ayat (1), Pasal 28D ayat (1), Pasal 28E ayat (1), Pasal 28E ayat (2), Pasal 28E ayat (3), Pasal 28I ayat (1), Pasal 28I ayat (2), dan Pasal 29 ayat (2).

\section{KESIMPULAN}

Menurut hukum Islam, tindak pidana agama adalah perbuatan-perbuatan yang mencemarkan (tadnis), menghina (istihza), mengolok-olok (syatama), mencerca (saba) dan memaki (tha'an) Allah dan Rasulnya, Kitab Suci Al-Qur'an, menyerang akidah Islamiyah, serta melakukan perbuatan-perbuatan yang menyimpang dari tuntunan ajaran-ajaran Islam.

Menurut hukum positif, tindak pidana agama dibedakan menjadi; a) Delik agama, yaitu perbuatan-perbuatan yang menyimpang (heresy) dari ajaran agama, perbuatan-perbuatan yang menodai (blasphemy), menista agama (defamation of religion), dan mengajak orang tidak beragama (atheism) seperti yang diatur dalam Pasal 156a KUHP, serta perbuatan atau ekspresi kebencian terhadap golongan agama (hate speech), seperti yang diatur dalam Pasal 156 KUHP; dan b) Delik yang berhubungan dengan agama.

Negara-negara sekuler di Eropa cenderung menghapus keberadaan delik agama (blasphemy law) dan menggantinya dengan delik penghinaan (defamation law). Kecenderungan ini dilatarbelakangi oleh bergesernya nilai-nilai budaya dan norma-

\footnotetext{
${ }^{16}$ Margiyono, Mutiono, Rumadi, Sulistyowati Irianto, Bukan Jalan Tengah, Eksaminasi Publik Putusan Mahkamah Konstitusi Perihal Pengujian UndangUndang Nomor 1/PNPS/1965 Tentang Pencegahan Penyalahgunaan dalatau Penodaan Agama, Penerbit The Indonesian Legal Resource Center, Jakarta, 2010.

17 ibid hlm Xiii.

18 ibid
} 
norma sosial dalam masyarakat yang mendorong terlepasnya agama dari moralitas dan legalitas. Agama tidak lagi menjadi objek yang perlu dilindungi oleh hukum, karena dipandang tidak lebih dari ideologi atau gagasan. Dalam perspektif hukum Indonesia, keberadaan delik agama sebagaimana yang diatur di dalam Undang-Undang Nomor 1/PNPS/1965 dan Kitab Undang-Undang Hukum Pidana, tidak bertentangan dengan hak-hak asasi manusia.

\section{E. REFERENSI:}

\section{Buku}

Abdurrahman, M. Mirza Ghulam Ahmad Plagiator Al-Qur'an Studi Banding Antara Ayatayat Tadzkirah Dan Ayat-ayat Al-Qur'an. Bandung: Rahman Press. 2015.

Al-Asqalany, Imam Al-Hafidz Ibnu Hajar. Bulughul Maram Five in One. Bandung: Penerbit Noura, 2017.

Al-Faifi, Sulaiman. Ringkasan Fiqih Sunnah Sayyid Sabic. Depok: Senja Media Utama, 2016.

Auda, Jasser. Maqasid Al-Shariah as Philosophey of Islamic Law. London: The International Institute of Islamic Thought. 2007

An-Naim, Abdullahi Ahmed. Islam and the Secular State. Harvard University Press, 2008.

Al Rasyid, Harun. Naskah UUD 1945 Sesudah Empat Kali Diubah oleh MPR. Jakarta: Penerbit Universitas Indonesia. 2007.

Ali, Mohammad Daud. Asas-asas Hukum Islam: Pengantar Ilmu Hukum dan Tata Hukum Islam di Indonesia. Jakarta: Rajawali Press. 1990.

Aji, A.M. Rasionalitas ijtihad Ibn Rusyd: kajian atas fiqh jinayat dalam kitab "Bidayat alMujtahid wa Nihayat al-Muqtashid, Bogor: Pustaka Pena Ilahi, 2010.

Aji, A.M.; Yunus, N.R. Basic Theory of Law and Justice, Jakarta: Jurisprudence Institute, 2018.Anshari, Endang Saifuddin. Piagam Jakarta 22 Juni 1945 Sebuah Konsensus Nasional Tentang Dasar Negara Republik Indonesia (1945-1949). Jakarta: Gema Insani Press, 1997.

Arief, Barda Nawawi. Delik Agama dan Penghinaan Tuhan (Blasphemy) di Indonesia dan Perbandingan Berbagai Negara, Semarang: BP Undip, 2007.

Arief, Barda Nawawi. Bunga Rampai Kebijakan Hukum Pidana Perkembangan Penyusunan Konsep KUHP Baru, Kencana Predana Media Group, Jakarta, 2008.

Asad, Talal. Reflections on Blasphemy and Secular Criticism. Fordham University Press. 2008.

Azhary, Muhammad Tahir. Negara Hukum Suatu Studi tentang Prinsip-Prinsipnya Dilihat dari Segi Hukum Islam, Implementasinya pada Periode Negara Madinah dan Masa Kini. Jakarta: Blan Bintang, 1992.

Basyir, Azhar. Ikhtisar Fikih Jinayat (Hukum Pidana Islam). Yogyakarta: UII Press, 2015. 
Bowen, J.R. Religions in Practice. Boston: Allyn \& Bacon, 1998.

Black's Law Dictionary. Seventh Edition, West Group St. Paul Minn. 1991.

Budiardjo, Miriam. Dasar-Dasar Ilmu Politik. Jakarta; Gramedia Pustaka Utama, 2010.

Buku Pedoman Dasar Kerukunan Hidup Beragama 1985-1986. Jakarta: Sekretariat Jenderal Departemen Agama RI, 1986.

Chalil, Munawar. Definisi dan Sendi Agama. Jakarta: Bulan Bintang, 1970.

Coleman, Elizabeth Burns \& White, Kevin (Editors). Negotiating the Sacred Blasphemy and Sacrilege in a Multicultural Society. Canberra: The Australian National University, 2007.

Departemen Agama RI. Kompilasi Peraturan Perundang-undangan Kerukunan Hidup Umat Beragama. Jakarta: Badan Litbang Agama dan Diklat Keagamaan Puslitbang Kehidupan Beragama, 2004.

Effendy, Marwan. Teori Hukum dari Perspektif Kebijakan Perbandingan dan Harmonisasi Hukum Pidana. Jakarta: Gaung Persada Press Group. 2014.

Fadjar, Abdul Mukti.Hukum Konstitusi \& Mahkamah Konstitusi. Jakarta: Konstitusi Press, 2006.

Fakultas Hukum UNISBA, Hukum Untuk Manusia, Kado (tak) Istimewa Dari Fakultas Hukum UNISBA untuk Indonesia, Diterbirkan oleh Pilar Utama Mandiri bekerjasama dengan Pelaksana Peringatan Milad Fakultas Hukum Unisba ke-41 tahun, Bandung, 2012.

Feurbach, Ludwig. The Essence of Christianity. Newe York: Prometheus Books, 1989.

Feith, Herbert \& Castles, Lance. Pemikiran Politik Indonesia 1945-1965. Jakarta: Lembaga Penelitian, Pendidikan dan Penerangan Ekonomi dan Sosial. 1988.

Fiss, Joelle and Kestenbaum, Jocelyn Getgen. Respecting Rights? Measuring The World's Blasphemy Laws. Washington: United State Commission On International Religious Freedom, 2017.

Fitzgerald. Salmond on Jurisprudence. London: Sweet and Maxwell. 1966.

Gazalba, Sidi. Mesjid Pusat Ibadat Dan Kebudayaan Islam. Jakarta: Pustaka Antara. 1983.

Hasan, Mustofa.Saebani, Beni Ahmad. Figh Jinayah.Hukum Pidana Islam. Bandung: 2013.

Hathout, Maher, with Uzma Jamil, Gasser Hathout \& Nayyer Ali. In Pursuit of Justice the Jurisprudence of Human Rights in Islam. Los Angeles: Muslim Public Affairs Council, 2006.

Heryanto, Budiman \& Tim Kompilasi KPT GKISW Jabar, Calvinis Aktual. Jakarta: Komisi Pengkajian Teologi (KPT) Gereja Kristen Indonesia Sinode Wilayah Jawa Barat, 2010.

Huijbers, Theo. Filsafat Hukum dalam Lintasan Sejarah. Yogyakarta: Kanisius. 1995.

Irfan, M. Nurul. Hukum Pidana Islam. Jakarta: Amzah. 2016. 
Irfan, M. Nurul \& Masyrofah. Fiqh Jinayah. Jakarta: Amzah. 2015.

Khaldun, Ibnu. Al-Allamah Abdurrahman bin Muhammad bin. Mukaddimah (Edisi Indonesia). Jakarta: Pustaka Al-Kautsar, 2011.

Kurzman, Charles (Ed). Islam Liberal Pemikiran Islam Kontemporer tentang Isu-Isu Global. Jakarta: Paramadina, 2001.

Lev, Daniel S. Hukum dan Politik Di Indonesia, Kesinambungan dan Perubahan. Terjemahan Nirwono dan A.E. Priyono. Jakarta: LP3ES, 1990.

Lev, Daniel S. Peradilan Agama Islam di Indonesia. Jakarta: Intermasa, 1986.

Lewis, Bernard. The Crisis of Islam.Holy War and Unholy Terror. New York: The Modern Library, 2003.

Mahmassani, Subhi. Konsep Dasar Hak-Hak Asasi Manusia, Studi Perbandingan Dalam Syariat Islam dan Perundang-undangan Modern. Jakarta: Tintamas, 1993.

Manan, Bagir (Editor). Kedaulatan Rakyat, Hak Asasi Manusia, dan Negara Hukum. Jakarta: Gaya Media, 1996.

Margiono. Muktiono.Rumadi. Irianto, Soelistyowati. Bukan Jalan Tengah Eksaminasi Publik Putusan Mahkamah Konstitusi Perihal Pengujian Undang-Undang Nomor 1 PNPS Tahun 1965 Tentang Penyalahgunaan dan/atau Penodaan Agama. Jakarta: The International Legal Resource Center, 2010.

Maggalatung, A.S.; Aji, A.M.; Yunus, N.R. How The Law Works, Jakarta: Jurisprudence Institute, 2014?

Muslich, Ahmad Wardi. Hukum Pidana Islam. Jakarta: Sinar Grafika, 2016.

Namazie, Maryam.Mahmoud, Nahla.Khatiri, Atoosa. Political and Legal Status of Apostates in Islam. London: Council of Ex Muslims of Britain, 2013.

Nasution, Harun dan Effendy, Bachtiar (Ed.) Hak Azasi Manusia Dalam Islam. Jakarta: Yayasan Obor Indonesia, 1987.

Natsir, Mohammad. Agama dan Negara Dalam Persepektif Islam. Jakarta: Media Dakwah, 2001.

Natsir, Mohammad. Capita Selecta 2. Jakarta: PT Abadi dan Yayasan Capita Selecta, 2008.

Natsir, Mohammad. Capita Selecta 3. Jakarta: PT Abadi dan Yayasan Capita Selecta, 2008.

Noer, Deliar. Gerakan Moderen Islam di Indonesia 1900-1942. Jakarta: LP3ES, 1996.

Otto, Jan Michiel. Sharia Incorporated A Comparative Overview of the Legal System of Twelve Muslim Countries in Past and Present. The Hague: Leiden University Press, 2010.

Panitia Penulisan Buku 70 Tahun Prof.DR.H.M. Rasjidi. Jakarta: Harian Umum Pelita, 1985.

Patrick, John.J. and Long, Greald.P. Constitutional Debates On Freedom of Religion. Connecticut: Greenwood Press, tanpa tahun.

Poerwadarminta, WJS. Kamus Umum Bahasa Indonesia. Jakarta: Balai Pustaka, 1989. 
Praja, Juhaya. S. Filsafat Hukum Antar Madzhab-Madzhab Barat dan Islam. Bandung: Latifah Press. 2014.

Praja, Juhaya. Delik Agama Dalam Hukum Pidana Di Indonesia. Bandung: Angkasa, 2007.

Praja, Juhaya. Teori Hukum Dan Aplikasinya, CV Pustaka Setia, Bandung, 2011.

Praja, Juhaya. Filsafat Hukum Antar Madzhab-Madzhab Barat Dan Islam, Penerbit Latifah Press Institut Agama Islam Latifah Mubarokiyah (IAIILM) Pondok Pesantren Suryalaya, Tasikmalaya Jawa Barat, Bandung, 2014.

Rahardjo, M. Dawam. Merayakan Kemajemukan Kebebasan Dan Kebangsaan. Jakarta: Kencana, 2010.

Rahman, Fazlur. Tema-Tema Pokok A-Qur'an. Bandung: MIzan, 2017.

Rasyidi, H.M. Sekulerisme Dalam Persoalan Lagi? Suatu Koreksi atas tulisan Drs. Nurcholis Madjid tentang Sekulerisasi. Jakarta: Yayasan Bangkit, 1972.

Rasyidi, H.M. Koreksi Terhadap DR Harun Nasution tentang" Islam ditinjau dari berbagai aspeknya'. Jakarta; Bulan Bintang, 1977.

Rasyidi, H.M. Empat Kuliah Agama Islam Pada Perguruan Tinggi. Depok: Kalam Ilmu Indonesia, 2011.

Rasyidi, H.M. Islam dan Kebatinan. Jakarta: Bulan Bintang, 1967.

Regus, Max. Understanding Human Rights Culture in Indonesia: A Case Study of the Ahmadiyya Minority Group. Tilburg University, 2017.

Roberts, Keith.A. Religion in Sociological Perspective. Illinois: The Dorsey Press, 1984.

Rousseau, Jean-Jacques. Perihal Kontrak Sosial atau Prinsip-Prinsip Hukum Politik. Jakarta:PT Dian Rakyat, 1989.

Sadurski, Wojciech. Moral Pluralism and Legal Neutrality. Dordrecht: Kluwer Academic Publishers, 1990.

Saleh, K. Wantjik. Tiga Undang-Undang Dasar. Jakarta: Ghalia Indonesia. 1977.

Santoso, Topo. Asas-Asas Hukum Pidana Islam, PT RajaGrafindo Persada, Jakarta, 2006.

Schmid, JJ. Von. Grote Denkers Over Staat en Recht (Van Plato Tot Kant). Terjemahan Ahliahli Pikir Besar Tentang Negara dan Hukum dari Palto sampai Kant. R. Wiranto dkk. Jakarta: Pembangunan. 1965.

Sekretariat Negara Republik Indonesia, Risalah Sidang Badan Penyelidik Usaha-Usaha Persiapan Kemerdekaan Indonesia (BPUPKI) Panitian Persiapan Kemerdekaan Indonesia (PPKI) 28 Mei 1945 - 22 Agustus1945. Jakarta 1995.

Seno Adji, Oemar. Hukum (Acara) Pidana Dalam Prospeksi. Jakarta: Eralngga, 1984.

Setiadi, Edi. Bunga Rampai Hukum Pidana, Penerbit Fakultas Hukum Universitas Islam Bandung, Bandung, 2004.

Setiadi, Edi. dan Kristian Sistem Peradilan Pidana Terpadu Dan Sistem Penegakan Hukum 
Di Indonesia, Prenadamedia Group, Jakarta, 2017.

Soeseno, Franz Magnis. Etika Politik. Prinsip-prinsip Moral Dasar Kenegaraan Modern. Jakarta: Gramedia Pustaka Utama.1999.

Soeseno, Franz Magnis.Filsafat Sebagai Ilmu Kritis. Yogyakarta: Kanisius, 1992.

Stirling, J.H. Lectures on the philosophy of law. London: Longmans \& Co, 1873.

Subekti, Valkina Singka. Menyusun Konstitusi Transisi Pergulatan Kepentingan dan Pemikiran dalam Proses Perubahan UUD 1945. Jakarta:PT RajaGrafindo Persada, 2008.

Suhelmi, Ahmad. Pemikiran Politik Barat Kajian Sejarah Perkembangan Pemikiran Negara, Masyarakat dan Kekuasaan. Jakarta: Gramedia Pustaka Utama, 2001.

Suminto, H. Aqib. Politik Islam Hindia Belanda. Jakarta: Lembaga Penelitian Pendidikan dan Penerangan Ekonomi dan Sosial, 1986.

Suryadinata, Leo. Arifin, Evi Nurvidya. Aris, Ananta. Penduduk Indonesia Etnis dan Agama Dalam Era Perubahan Politik. Hjakarta: LP3ES, 2003.

Suseno, Franz Magnis. Etika Politik. Jakarta: Gramedia Pustaka Utama, 2001.

Valerine, J.L.K. (Pengumpul). Metode Penelitian Hukum. Jakarta: Pascasarjana Fakultas Hukum Universitas Indonesia, 2009.

Wahjono, Padmo. Negara Republik Indonesia., Jakarta: PT RajaGrafindo Persada, 1995.

Yamin, Muh. Naskah Persiapan Undang-Undang Dasar 1945. Jakarta: Jajasan Prapantja, 1959.

Zainuddin, A. Rahman. Kekuasaan Dan Negara Pemikiran Politik Ibnu Khaldun. Jakarta: PT Gramedia Pustaka Utama, 1992.

\section{Artikel}

Brugger, Wienfried. On the Relationship between Structural Norms and Constituional Rights in Curch-State Relations.

Manan, Bagir. Persepsi Pancasila dan UUD 1945 Terhadap Hak Asasi Manusia. Makalah disampaikan pada Seminar Nasional Sehari, FH UNISBA, September 1995.

Mootz III, Francis J. Faith and Politics in the Post-Secular Age: The Promise of President Obama. (2009). University of Nevada, Las Vegas - William S. Boyd School of Law. Scholarly Works Paper 60. http://scholars.law.unlv.edu/facpub/60.

Nammour, Jihad. State and Religion Comparing Cases of Changing Relations A Conference Report with original contributions by Dominik Hanf, Albert Peter Rethmann and Franz Magnis Suseno. Beirut: Friedrich Ebert Stiftung, 2011.

Nieuwenhuis, Aernout. European Court of Human Rights. State and Religion, Schools and Scarves, An Analysis of the Margin of Appreciation as Used in the Case of Leyla Sahin v. Turkey. Decision of 29 June 2004, Application Number 44774/98. 
Calo, Zachary R. Religion, Human Rights, and Post-Secular Legal Theory. Rt. John's Law Review: Vol. 85: $\quad$ Iss. 2, 4 http://scholarship.law.stjohns.edu/lawreview/vol85/iss2/5

Modak-Truran, Mark C. Secularization, Legal Indeterminacy, And Habermas's Discourse Theory of Law. Florida State University Law Review, 35 FLA. ST. U.L.REV.73 (2007).

Modak-Truran, Beyond Theocracy and Secularism (Part I): Toward A New Paradigm for Law and Religion. http://works.bepress.com/mark modak truran/2

Gulalp, Haldun. Secularism in Europe, As Refracted through the Prism of the European Court of Human Rights: Comparative Analysis of State-Church Relations and the State Regulation of Religion. JURISTRAS project funded by the European Commission, DG Research, Priority 7, Citizens and Governance in a Knowledge Based Society (Contract no: FP6-028398).

Backer, Larry Cata. Religion As Object And The Grammar Of Law. Marquette Law Review. http://scholarship.law.marquette.edu/mulr/vol81/iss/5

Esposito, John L. Retreat from the Secular Path: The Democracy-Secularism Debate in the Muslim World. Quaderni di Relazioni Internazionali n.12 April 2010.

Gavino, Victor C. Religious Liberty and Blasphemy Law in Indonesia: Position Paper. Relg550. 22 Juli 2013.

\section{Lain-lain.}

Indische Staatsregering.

The Universal Declaration of Human Rights.

International Covenant on Civil and Political Rights 1966. 
Didi Hilman

46 - Fakultas Agama Islam Universitas Ibn Khaldun Bogor 